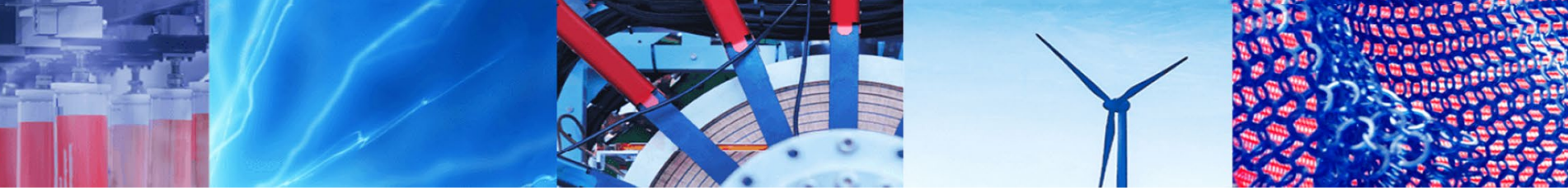

Research Article

\title{
Hydraulic geometry analysis of Ceyhan River, Turkey
}

\author{
Mehmet Ishak Yuce ${ }^{1}$ (D) Musa Esit ${ }^{2} \cdot$ Meltem Ciloglan Karatas $^{1}$
}

(c) Springer Nature Switzerland AG 2019

\begin{abstract}
Depth, width, velocity and suspended load are critical fluvial hydraulic characteristics, which mainly determine the shape of the cross-section of a river. The aim of this study is to determine at-a-station and the downstream hydraulic geometry parameters and obtain a relationship between sediment discharge and flow discharge of the Ceyhan River. Eleven hydrological stations were utilised in the analyses which are located on the river and its tributaries. Three of these stations have sediment, flow discharge and cross-sectional data, while four of them have only sediment and flow discharge and the other four have only flow discharge and cross-sectional data. The downstream hydraulic geometry parameters $b, f, m, a, c$ and $k$ were found to be $0.33,0.38,0.29,14.82,0.61$ and 0.12 , respectively. At-a-station hydraulic geometry parameters $b, f, m, a, c$ and $k$ were found to be $0.1676,0.00654,0.7669,25.676,1.8542$ and 0.0901 , respectively. A good power function correlation was noted between the sediment discharge and flow discharge with the average coefficient and exponent of 1.23 and 2.05, respectively. The results of the study are expected to be valuable for water resources planning and management projects in the basin.
\end{abstract}

Keywords Hydraulic geometry · Downstream hydraulic geometry · At-a-station hydraulic geometry · Ceyhan River . Sediment load

\section{Introduction}

Due to growing population, human activities especially in developing countries, water management is of great importance in watershed. To meet water resource demand, appropriate management of river basins is a necessity. For this purpose, comprehending the hydraulic geometry of river channels and their behaviours is important. The measurable hydraulic characteristics which constitute the form of rivers such as depth, width and velocity are achieved by expressing these values as a power function of flow discharge. These exponential relationships between the hydraulic geometry parameters and the flow discharge are called hydraulic geometry [1]. Hydraulic geometry can be applied either for at-a-station approach in which the changes in a particular cross-section is taken into consideration or downstream approach where changes all along the river channel and its branches are considered [2]. Both approaches were considered in this study. Hydraulic geometry is formulated by Leopold and Maddock [1] as a power function of flow discharge;

$B=a Q^{b}$

$H=c Q^{f}$

$V=k Q^{m}$

where $Q$ is flow discharge, $B$ is the water surface width, $H$ is the average water depth, $V$ is the average flow velocity; $a, b, c, f, k$ and $m$ are numerical constants. For rectangular channels width, depth and velocity satisfy the continuity equation which means summation of the exponents and multiplication of coefficients are equal to 1 (Eqs. 5, 6).

$\triangle$ Mehmet Ishak Yuce, yuce@gantep.edu.tr; Musa Esit, mesit@adiyaman.edu.tr; Meltem Ciloglan Karatas, mltm.clg@gmail.com | ${ }^{1}$ Department of Civil Engineering, Gaziantep University, Gaziantep, Turkey. ${ }^{2}$ Department of Civil Engineering, Adıyaman University, Adiyaman, Turkey. 
Hydraulic geometry relation accepts that the flow is steady and uniform. A power function method is utilised to find the exponents and the coefficients.

$Q=B H V$

$a c k=1$

$b+f+m=1$

Due to the importance and practical usage, many researchers have focused on hydraulic geometry content. Over the last decades, a lot of hydraulic geometry studies have been reported all over the world.

Leopold and Maddock [1] introduced hydraulic geometry theory by analysing the cross-sectional data of 20 rivers and found $b, f$ and $m$ values to be $0.26,0.40$ and 0.34 , respectively, for at-a-station hydraulic geometry, while for downstream hydraulic geometry these values were noted to be $0.50,0.40$ and 0.10 , respectively. Leopold et al. [3] stated that, in downstream hydraulic geometry, the width has tendency to increase more consistent than any other morphologic variable, as a square root of the discharge, while mean velocity tends to increase slightly at the downstream in most rivers. Chong [4] has realised that hydraulic geometry relations can be similar for different river environments. Richards [5] affirmed that the power relationships can be used for forecasting various types of channel crosssections. Park [6] has studied 139 at-a-station sites and 72 downstream cases. The average values of $b, f$ and $m$ exponents were noted to be around $0.4-0.5,0.3-0.4$ and $0.1-0.2$, respectively.

Huang and Warner [7] introduced that the coefficient of hydraulic geometry parameters is related to hydraulic roughness (Manning's n), slope and bank strength. Huang and Nanson [8] examined bank vegetation and found that dense bank vegetation causes narrower channels, while bed vegetation increases the flow resistance and causes wider channels, reduction in flow velocity and no significant change in depth. Singh [2] and Park [6] analysed the $b, f$ and $m$ values for different studies collected from literature for both at-a-station and downstream cases. Parker [9] realised that the $b, f$ and $m$ values show a similarity for different regions, while $a, c$ and $k$ values can be different from region to region. Kolberg and Howard [10] and Howard [11] stated that hydraulic geometry parameters show variations, depending on the bed material of alluvial channels. Rhoads [12] has explored variations of the hydraulic geometry and affirmed that generally the coefficients are more variable than the exponents. Since collecting real channel data is expensive and cumbersome, Allen et al. [13] recommended that hydraulic geometry relations are sufficient for planning-level models and with the combination of other analytical methods, it can be cost-effective and practical design method. Huang and Nanson [14] stated that the hydraulic geometry exponents show significant variation from one stream to another. Stewardson [15] has observed that change of hydraulic geometry parameter is connected to type of rivers, flow parameters, sediment load and bank material. For downstream studies of hydraulic geometry parameters of alluvial channels, a huge set of data is collected by Lee and Julien [16]. De Rose et al. [17] have studied downstream hydraulic geometry of the Victoria River and analysed 93 sites. For narrow and deep channels, Nanson and Huang [18] found that when flow velocity changes rapidly, water depth changes moderately and water surface width almost does not change.

Downstream hydraulic geometry of the Tigris River was determined by Muratoglu and Yuce [19]. The $b, f$, and $m$ exponents for the Tigris River were found to be $0.469,0.468$ and 0.077 , while $a, c$ and $k$ coefficients were observed to be $8.17,0.18$ and 0.66 , respectively. Yuce et al. [20] determined the hydraulic geometry parameters of the Seyhan River and found $b, f$ and $m$ values of the downstream hydraulic geometry as $0.11,0.56$ and 0.33 , respectively. Wilson [21] stated that the movements of sediment material in the rivers are in two different forms: bed load and suspended load. He described the bed load as part of the total load that passes right above the bed and affirmed this bearing load is being supported by intergranular collisions rather than liquid turbulence, while suspended load is a part of the load, especially supported by the turbulence of flow. The geological, topographical and climatic factors affecting sediment transport are numerous; the relationship to each other is too complex to analytically calculate the amount of sediment carried by any stream. Although there are many different estimation methods developed for this purpose, direct measurements results are always more reliable than calculations [22]. Due to the increase in rural population, sediment transport and erosion rate are increasing [23, 24]. For downstream studies of hydraulic geometry parameters of alluvial channels, a huge set of data is collected by Lee and Julien [16].

Eaton and Church [25] tested rational regime theory. They first tested the cases in which bank strength does not vary greatly and then tested the modified bank strength formula for vegetated gravel bed rivers in which bank strength changes with channel scale. The classical hydraulic geometry was found to show only an insignificant variation of channel form. Booker and Dunbar [26] established a method to predict hydraulic geometry of UK channels. Donald E. Reid et al. [27] investigated 61 cross-sections in British Columbia and noted that the mean velocity changes more rapidly with discharge. In 31 of 61 cross-sections, velocity exponent $(m)$ was observed to be greater than the width and depth exponents combined. The average value of $m$ was calculated to be 
0.51 , while average values of $b$ and $f$ were 0.20 and 0.29 , respectively. Aisuebeogun et al. [28] noted that widthto-depth ratio is related to percentage of silt and clay in the channel perimeter. Julien [29] described downstream hydraulic geometry in three ways such as empirical concept, theoretical developments and equivalent channel width.

Ternary diagram of hydraulic geometry exponents apparently demonstrates differences and similarities among the basin system by showing simultaneously the value of all three exponents with time. Interpreted exponents give an idea about stream. While $b>f$ becomes a channel wider and shallower downstream, $f>b$, depth increases faster than width, shows a channel cross-section relatively deeper and narrower. $m=0$ states that the channel velocity doesn't change with time. When $m=0.5$, velocity increases rapidly in stream than area [31].

As lots of studies have been conducted about hydraulic geometry, including the ones mentioned above, hydraulic geometry is of great importance. First, hydraulic geometry relations are very practical to forecast fluvial processes of alluvial channel. Determining hydraulic geometry parameters of rivers is essential for design and management of hydraulic works, channel training works, flood control, hydropower generation, irrigation works, channel improvements, and so on. Under-sizing the river channel may cause severe flood problems, while oversizing the channel may start the degradation of biodiversity [30]. In order to develop sustainable and cost-effective river management strategies, hydraulic geometry parameters and sedimentations are of great importance, which helps to predict the physical characteristics of river systems for future works.

\section{Study area and data}

Ceyhan River Basin is situated in the eastern Mediterranean region, within the boundaries of Turkey. The catchment lies between $36^{\circ} 33^{\prime}$ to $38^{\circ} 44^{\prime}$ North latitudes and $35^{\circ} 15^{\prime}$ to $37^{\circ} 43^{\prime}$ East longitudes. It is bounded by the Seyhan River Basin in the west and northwest, the Asi River Basin in the south and the Euphrates River Basin in the east and northeast. Ceyhan River reaches the Mediterranean Sea, near the city of Adana (Fig. 1).

In this study, eleven flow and sediment stations were utilised. Three of these stations have sediment and discharge data, while four of them have only sediment and the other four have only discharge data (Fig. 1). The mean daily discharges, the channel cross-sectional data and sediment measurement data were collected from General Directorate of State Hydraulic Works of Turkey (DSI). In the analysis of every single station, the cross-sectional area data were utilised with the corresponding daily discharge values.

At-a-station and downstream hydraulic geometry parameters were calculated by employing power function analysis. A time period of 7 years ranging from 2004 to 2010 was considered in the investigation in order to
Fig. 1 Ceyhan River Basin and the flow and sediment measurement stations

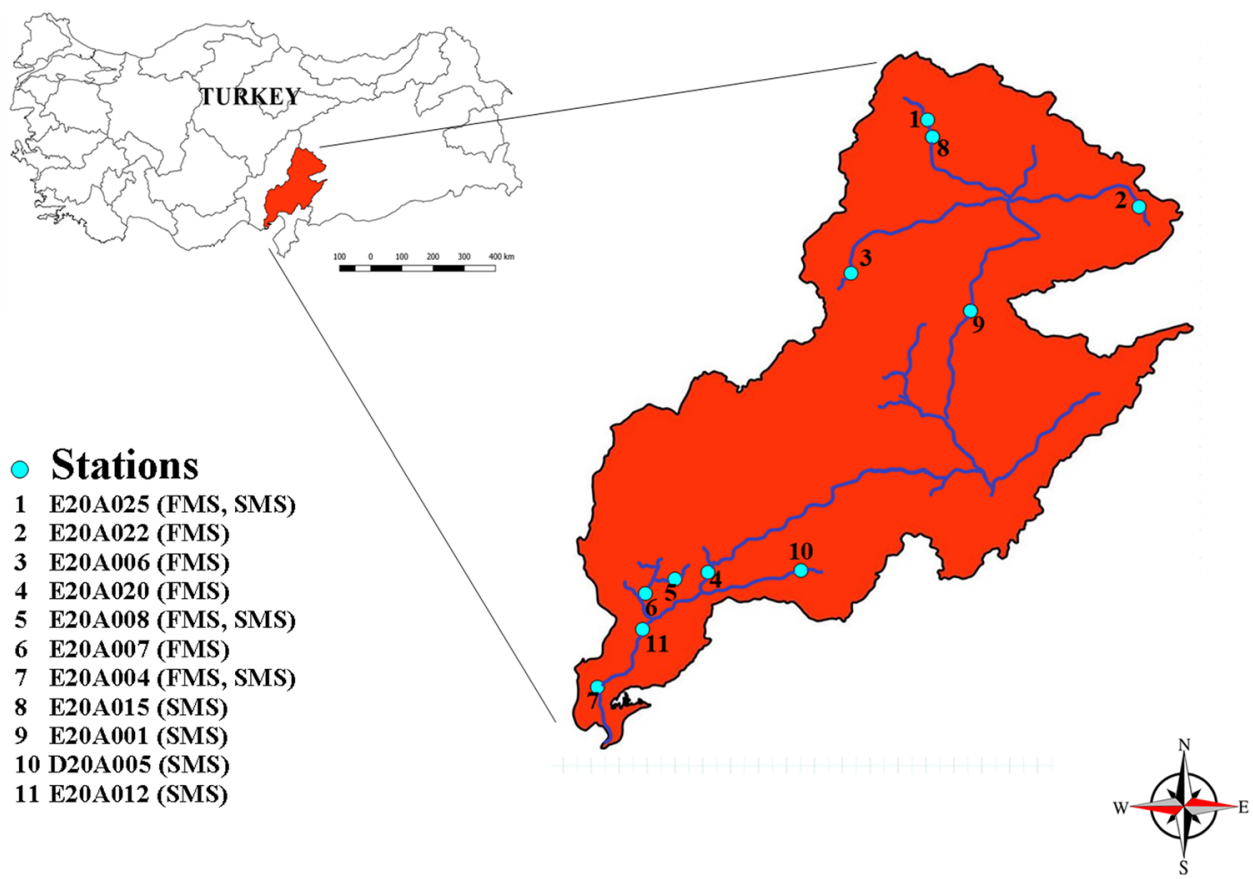

SN Applied Sciences A SPRINGER NATURE journa 
Table 1 Flow measurement stations

\begin{tabular}{|c|c|c|c|c|c|c|c|}
\hline Stations & $\begin{array}{l}\text { Available flow } \\
\text { measurements }\end{array}$ & $\begin{array}{l}\text { Available cross- } \\
\text { sections }\end{array}$ & Drainage area $\left(\mathrm{km}^{2}\right)$ & Latitude & Longitude & Altitude (m) & $\begin{array}{l}\text { Sediment dis- } \\
\text { charge (ton/ } \\
\text { day) }\end{array}$ \\
\hline E20A004 & 1985-2014 & 2004-2010 & 20,466 & $36^{\circ} 57^{\prime} 28^{\prime \prime}$ & $35^{\circ} 38^{\prime} 03^{\prime \prime}$ & 15 & 7047.77 \\
\hline E20A006 & 1985-2014 & 2003-2010 & 739.2 & $38^{\circ} 01^{\prime} 55^{\prime \prime}$ & $36^{\circ} 34^{\prime} 11^{\prime \prime}$ & 1324 & - \\
\hline E20A007 & 1985-2014 & 2003-2010 & 623 & $37^{\circ} 20^{\prime} 29^{\prime \prime}$ & $35^{\circ} 55^{\prime} 03^{\prime \prime}$ & 35 & - \\
\hline E20A008 & 1985-2014 & 2003-2010 & 480 & $37^{\circ} 21^{\prime} 43^{\prime \prime}$ & $36^{\circ} 05^{\prime} 05^{\prime \prime}$ & 70 & 389.13 \\
\hline E20A020 & 1985-2011 & 2002-2010 & 14,705 & $37^{\circ} 16^{\prime} 01^{\prime \prime}$ & $36^{\circ} 16^{\prime} 32^{\prime \prime}$ & 83 & - \\
\hline E20A022 & 1986-2015 & 2004-2010 & 400 & $38^{\circ} 15^{\prime} 20^{\prime \prime}$ & $37^{\circ} 32^{\prime} 01^{\prime \prime}$ & 1347 & - \\
\hline E20A025 & 1996-2015 & 2004-2010 & 914.7 & $38^{\circ} 25^{\prime} 19^{\prime \prime}$ & $36^{\circ} 55^{\prime} 12^{\prime \prime}$ & 1222 & 82.97 \\
\hline E20A001 & 1968-1991 & - & 8484 & $37^{\circ} 37^{\prime} 15^{\prime \prime}$ & $36^{\circ} 47^{\prime} 54^{\prime \prime}$ & 18 & 3750.20 \\
\hline E20A012 & 1953-1965 & - & $19,778.8$ & $37^{\circ} 01^{\prime} 57^{\prime \prime}$ & $35^{\circ} 48^{\prime} 43^{\prime \prime}$ & 30 & $42,881.80$ \\
\hline E20A015 & 1956-1989 & - & 915.2 & $38^{\circ} 25^{\prime} 21^{\prime \prime}$ & $36^{\circ} 55^{\prime} 14^{\prime \prime}$ & 1180 & 65.80 \\
\hline D20A005 & 1961-2013 & - & 94 & $37^{\circ} 05^{\prime} 58^{\prime \prime}$ & $36^{\circ} 20^{\prime} 12^{\prime \prime}$ & 265 & 19.34 \\
\hline
\end{tabular}

find a relationship between the flow discharge and the hydraulic geometry components of the river. The flow measuring stations utilised in the study are detailed in Table 1. The measured hydraulic characteristics of these seven flow measurement stations are presented in Table 2. Variations of hydraulic parameters are examined for two cases: (1) variations at a specific cross-section, which is known as at-a-station hydraulic geometry, and (2) variations along the channel, which is called downstream hydraulic geometry.

\section{Materials and methods}

\subsection{At-a-station hydraulic geometry}

At-a-station hydraulic geometry term is introduced by Leopold and Maddock [1] which is the relationship between the surface width, mean depth and mean flow velocity and water discharge. At-a-station hydraulic geometry brings out mean values over a certain period, such as a week, a month, a season or a year. In this approach, analyses are performed for a particular crosssection of the river, at a flow measurement station. A line fitted to the plot of daily discharge values versus the characteristics of the cross-sectional area of each station presents a power function which yields hydraulic geometry parameters. Graphics given in Fig. 2 represent ata-station relationships between the flow discharge and hydraulic geometry parameters (width, depth, velocity) for seven flow measurement stations on the Ceyhan River. Empirical equations were derived by using a power function analysis. The average values of the exponents $b, f$ and $m$ were found to be $0.1676,0.0654$ and 0.7669 , while the average values of the coefficients were noted to be $25.676,1.8542$ and 0.090 , respectively, for at-astation hydraulic geometry. For all stations apart from E20A020 and EA20A022 surface width, mean depth and mean flow velocity were observed to increase with increasing flow discharge. In E20A020 and EA20A022 measurement stations, the mean depth was noted to slightly decrease with increasing discharge which signifies shallow and wide cross-sections. At-a-station hydraulic geometry parameters are presented in Table 3 . Ternary diagrams (the exponents $b-f-m$ ) for at-a-station are shown in Fig. 3.

\subsection{Downstream hydraulic geometry}

The concept of downstream hydraulic geometry includes longitudinal changes in channel width, mean depth and mean flow velocity for a given discharge of water over a period of time. In this method, investigations are performed for a number of cross-sections of a river for the same period of time. A line fitted to the log-log scale plot of mean daily discharge values versus the hydraulic geometry parameters of cross-sectional areas of seven stations for a period of 7 years exhibits a power function. Diagrams illustrated in Fig. 4 demonstrate the downstream hydraulic geometry relationships between the flow discharge and hydraulic geometry parameters (width, depth, velocity) for 7 years. The empirical equations were acquired by employing a power function analysis. The average values of the exponents $b, f$ and $m$ were found to be $0.1676,0.0654$ and 0.7669 , while the average values of the coefficients were observed to be 
Table 2 Daily discharge values and corresponding hydraulic characteristics

\begin{tabular}{|c|c|c|c|c|c|c|}
\hline \multicolumn{2}{|c|}{$\begin{array}{l}\text { Flow measurement } \\
\text { stations }\end{array}$} & \multirow{2}{*}{$\begin{array}{l}\text { Average daily } \\
\text { discharge } \\
Q\left(\mathrm{~m}^{3} / \mathrm{s}\right)\end{array}$} & \multirow{2}{*}{$\begin{array}{l}\text { Cross-sectional } \\
\text { area } \\
A\left(\mathrm{~m}^{2}\right)\end{array}$} & \multirow{2}{*}{$\begin{array}{l}\text { Water surface } \\
\text { width } \\
B(\mathrm{~m})\end{array}$} & \multirow{2}{*}{$\begin{array}{l}\text { Average depth } \\
H(\mathrm{~m})\end{array}$} & \multirow{2}{*}{$\begin{array}{l}\text { Average velocity } \\
V(\mathrm{~m} / \mathrm{s})\end{array}$} \\
\hline No & Year & & & & & \\
\hline \multirow[t]{7}{*}{ E20A004 } & 2010 & 84.900 & 438.893 & 69.975 & 6.272 & 0.193 \\
\hline & 2009 & 54.700 & 423.543 & 70.979 & 5.967 & 0.129 \\
\hline & 2008 & 79.800 & 383.831 & 67.108 & 5.720 & 0.208 \\
\hline & 2007 & 88.700 & 406.607 & 70.276 & 5.786 & 0.218 \\
\hline & 2006 & 88.700 & 426.958 & 70.670 & 6.042 & 0.208 \\
\hline & 2005 & 102.000 & 413.957 & 70.750 & 5.851 & 0.246 \\
\hline & 2004 & 92.500 & 471.600 & 72.130 & 6.538 & 0.196 \\
\hline \multirow[t]{8}{*}{ E20A006 } & 2010 & 2.130 & 14.445 & 14.505 & 0.996 & 0.147 \\
\hline & 2009 & 1.670 & 16.710 & 16.150 & 1.035 & 0.100 \\
\hline & 2008 & 0.980 & 12.684 & 14.490 & 0.875 & 0.077 \\
\hline & 2007 & 2.700 & 13.951 & 16.081 & 0.868 & 0.194 \\
\hline & 2006 & 2.140 & 15.879 & 18.014 & 0.881 & 0.135 \\
\hline & 2005 & 2.560 & 17.248 & 17.724 & 0.973 & 0.148 \\
\hline & 2004 & 3.410 & 18.382 & 17.602 & 1.044 & 0.186 \\
\hline & 2003 & 3.230 & 17.289 & 17.213 & 1.004 & 0.187 \\
\hline \multirow[t]{8}{*}{ E20A007 } & 2010 & 5.660 & 15.000 & 15.874 & 0.945 & 0.377 \\
\hline & 2009 & 6.920 & 20.940 & 16.000 & 1.309 & 0.330 \\
\hline & 2008 & 3.200 & 20.550 & 16.000 & 1.284 & 0.156 \\
\hline & 2007 & 3.490 & 12.358 & 14.555 & 0.849 & 0.282 \\
\hline & 2006 & 4.060 & 12.322 & 14.742 & 0.836 & 0.329 \\
\hline & 2005 & 3.490 & 15.197 & 15.791 & 0.962 & 0.230 \\
\hline & 2004 & 4.530 & 20.810 & 16.000 & 1.301 & 0.218 \\
\hline & 2003 & 5.380 & 16.000 & 13.989 & 1.144 & 0.336 \\
\hline \multirow[t]{7}{*}{ E20A008 } & 2010 & 0.564 & 6.384 & 18.436 & 0.346 & 0.088 \\
\hline & 2009 & 1.300 & 13.402 & 23.869 & 0.561 & 0.097 \\
\hline & 2008 & 1.120 & 11.227 & 23.306 & 0.482 & 0.100 \\
\hline & 2007 & 1.450 & 29.894 & 35.500 & 0.842 & 0.049 \\
\hline & 2006 & 1.200 & 11.520 & 24.738 & 0.466 & 0.104 \\
\hline & 2005 & 0.760 & 11.717 & 25.575 & 0.458 & 0.065 \\
\hline & 2004 & 2.080 & 21.750 & 41.880 & 0.519 & 0.096 \\
\hline \multirow[t]{8}{*}{ E20A020 } & 2010 & 88.500 & 281.650 & 93.469 & 3.013 & 0.314 \\
\hline & 2009 & 66.900 & 134.586 & 72.184 & 1.864 & 0.497 \\
\hline & 2008 & 71.000 & 124.133 & 73.816 & 1.682 & 0.572 \\
\hline & 2007 & 8.680 & 120.760 & 70.982 & 1.701 & 0.072 \\
\hline & 2006 & 40.600 & 125.679 & 73.808 & 1.703 & 0.323 \\
\hline & 2005 & 70.500 & 156.560 & 75.000 & 2.087 & 0.450 \\
\hline & 2004 & 127.000 & 74.466 & 138.792 & 0.537 & 1.705 \\
\hline & 2003 & 118.000 & 79.410 & 173.661 & 0.457 & 1.486 \\
\hline \multirow[t]{7}{*}{ E20A022 } & 2010 & 0.323 & 3.824 & 13.146 & 0.291 & 0.084 \\
\hline & 2009 & 0.288 & 14.343 & 13.183 & 1.088 & 0.020 \\
\hline & 2008 & 0.170 & 4.029 & 13.015 & 0.310 & 0.042 \\
\hline & 2007 & 0.244 & 4.439 & 12.321 & 0.360 & 0.055 \\
\hline & 2006 & 0.331 & 4.415 & 12.705 & 0.348 & 0.075 \\
\hline & 2005 & 0.240 & 14.926 & 14.092 & 1.059 & 0.016 \\
\hline & 2004 & 0.450 & 5.890 & 14.690 & 0.401 & 0.076 \\
\hline \multirow[t]{7}{*}{ E20A025 } & 2010 & 4.260 & 6.142 & 9.746 & 0.630 & 0.694 \\
\hline & 2009 & 2.620 & 6.390 & 9.850 & 0.649 & 0.410 \\
\hline & 2008 & 3.130 & 5.478 & 9.640 & 0.568 & 0.571 \\
\hline & 2007 & 1.970 & 5.219 & 9.223 & 0.566 & 0.377 \\
\hline & 2006 & 3.290 & 6.112 & 10.272 & 0.595 & 0.538 \\
\hline & 2005 & 4.360 & 6.748 & 10.765 & 0.627 & 0.646 \\
\hline & 2004 & 3.800 & 6.246 & 10.287 & 0.607 & 0.608 \\
\hline
\end{tabular}



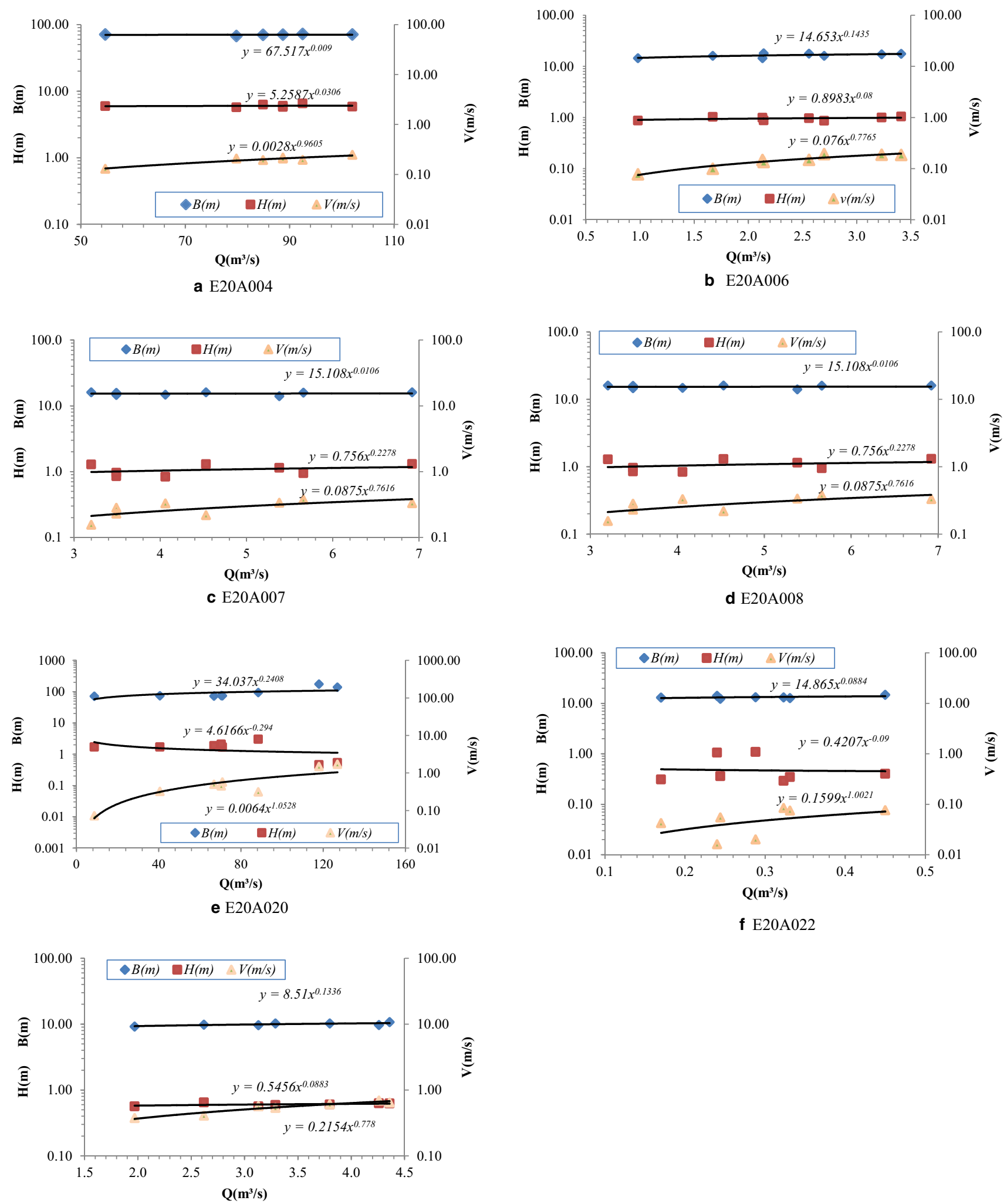

g E20A025

Fig. 2 Relationship between discharge and at-a-station hydraulic geometry parameters 
Table 3 The exponents and coefficients of at-aparameters station hydraulic geometry

\begin{tabular}{|c|c|c|c|c|c|c|c|c|}
\hline \multirow[t]{2}{*}{ Stations } & \multicolumn{3}{|c|}{ Exponents } & \multicolumn{3}{|c|}{ Coefficients } & \multirow[t]{2}{*}{$b+f+m$} & \multirow[t]{2}{*}{$a^{*} c^{*} k$} \\
\hline & $b$ & $f$ & $m$ & $a$ & c & $k$ & & \\
\hline E20A004 & 0.0090 & 0.0306 & 0.9605 & 67.5170 & 5.2587 & 0.0028 & 1.0001 & 0.9941 \\
\hline E20A006 & 0.1435 & 0.0800 & 0.7765 & 14.6530 & 0.8983 & 0.0760 & 1.0000 & 1.0004 \\
\hline E20A007 & 0.0106 & 0.2278 & 0.7616 & 15.1080 & 0.7560 & 0.0875 & 1.0000 & 0.9994 \\
\hline E20A008 & 0.5475 & 0.4154 & 0.0371 & 25.0420 & 0.4841 & 0.0825 & 1.0000 & 1.0001 \\
\hline E20A020 & 0.2408 & -0.2940 & 1.0528 & 34.0370 & 4.6166 & 0.0064 & 0.9996 & 1.0057 \\
\hline E20A022 & 0.0884 & -0.0900 & 1.0021 & 14.8650 & 0.4207 & 0.1599 & 1.0005 & 0.9999 \\
\hline E20A025 & 0.1336 & 0.0883 & 0.7780 & 8.5100 & 0.5456 & 0.2154 & 0.9999 & 1.0001 \\
\hline Average & 0.1676 & 0.0654 & 0.7669 & 25.676 & 1.8542 & 0.0901 & 1.00001 & 0.99997 \\
\hline
\end{tabular}

Fig. 3 Ternary diagram for $b-f-m$ exponents (representing width, depth and velocity, respectively) for at-a-station hydraulic geometry equations
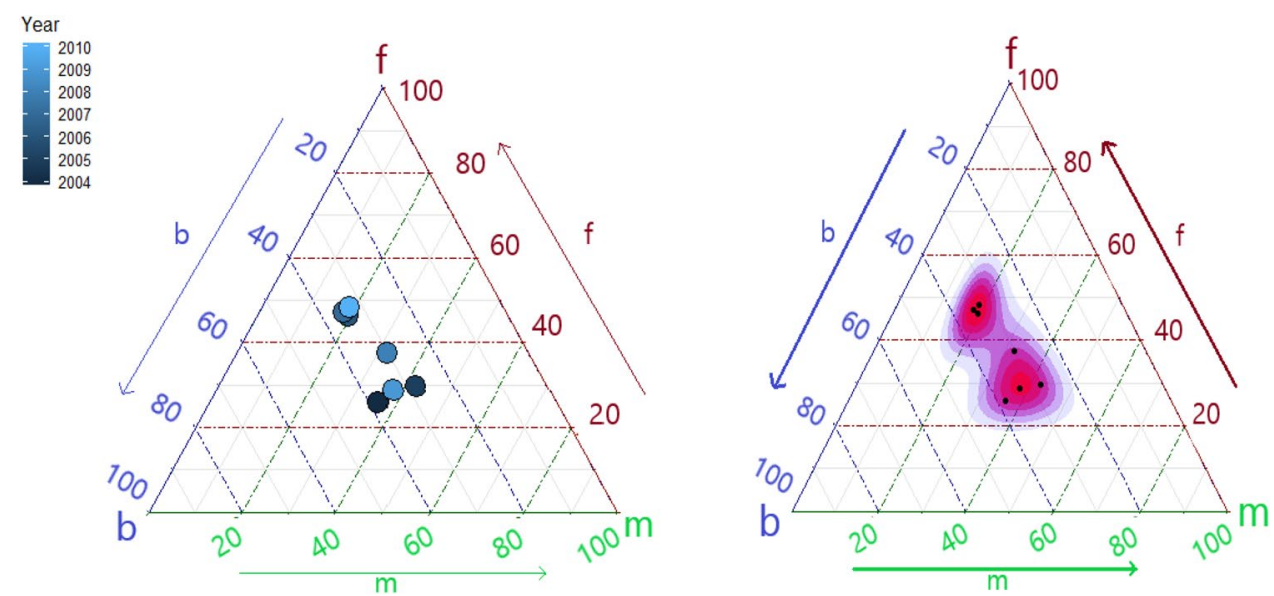

25.676, 1.8543 and 0.0901 , respectively, for downstream hydraulic geometry. The width, mean depth and mean flow velocity were observed to increase with increasing flow discharge. The downstream hydraulic geometry parameters are given in Table 4.

\subsection{Sediment discharge}

Rivers have a capacity to transport large volume of sediment while conveying water [29]. Hence, the term sediment discharge becomes an important factor for water resources management. The sediment volume transported by streams is critical for all hydraulic engineering projects. Power function analysis was utilised to determine the relationship between the river stream discharge and the sediment discharge, as in Eq. 7.

$Q_{\mathrm{s}}=p Q^{j}$

where $Q_{s}$ (tons/day) is the river sediment discharge, $Q$ $\left(\mathrm{m}^{3} / \mathrm{s}\right)$ is the river flow discharge, $p$ and $j$ are the coefficient and the exponent of power function, respectively. For the selected seven flow measurement stations, the log-log scale sediment rating curves $\left(Q-Q_{\varsigma}\right.$ relation) are graphically presented in Fig. 5 . In the analysis, it was observed that the sediment discharge is increasing with increasing flow discharge in all stations. The calculated coefficients and exponents of the power function are given in Table 5 .

In addition to power function analysis, the relationship between the flow discharge and the sediment discharge was examined by performing the correlation analyses. Kendall, Pearson and Spearman correlations were utilised to determine the correlation coefficients. The correlation coefficients between the sediment discharge and river flow discharge for the seven flow and sediment measurement stations on Ceyhan River are given in Table 6. While D20A005 and E20A025 stations show the strongest relationship between these variables, especially with Spearman's coefficient, $\rho$, the other stations, in general, indicate a meaningful relationship between the flow discharge and the sediment discharge with Pearson coefficient, $r$. As the coefficients are examined, it is clearly seen that all correlation values are positive; then, one can say that there is a positive correlation between the flow discharge and the sediment discharge. The Kendall (tau) analysis results show 


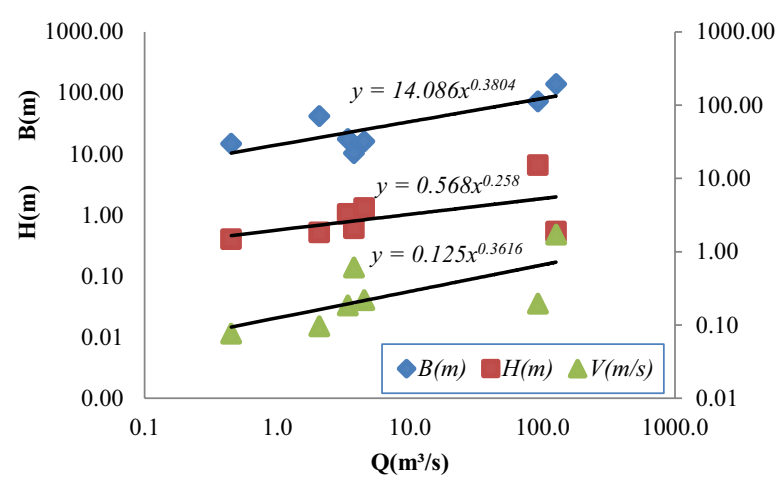

a 2004

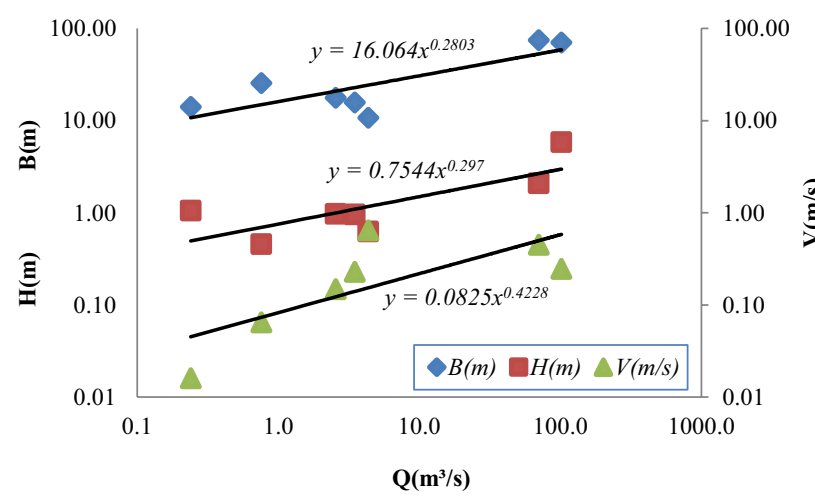

c 2006
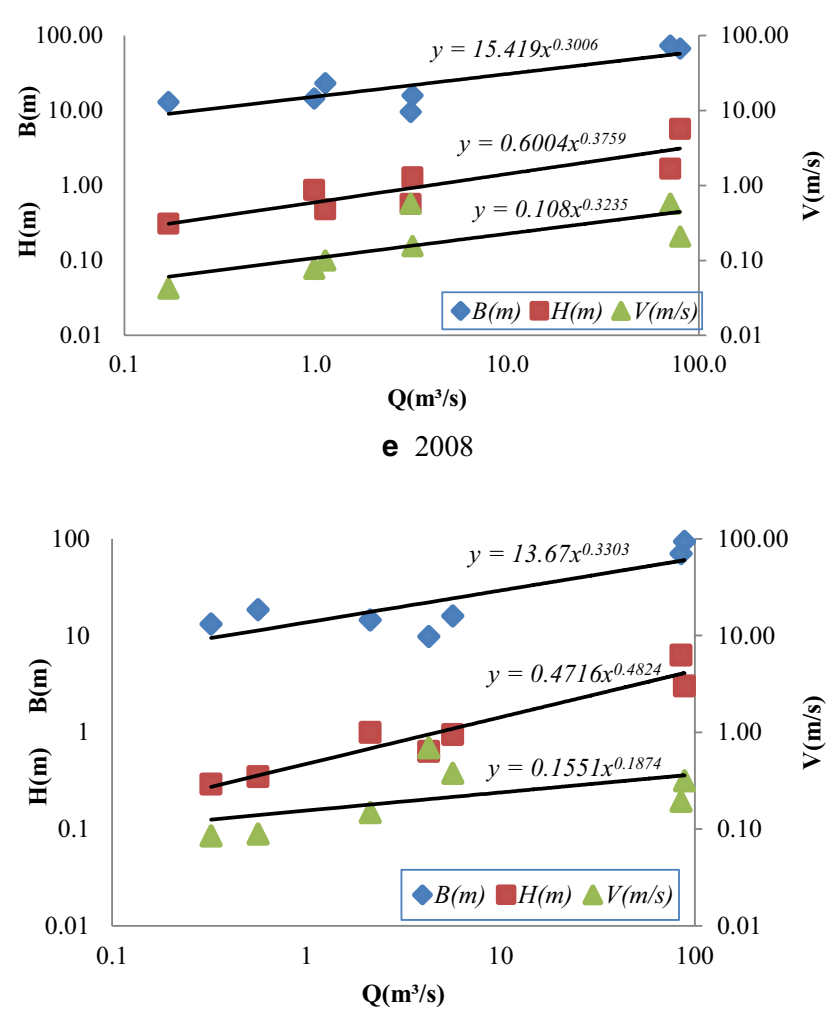

g 2010
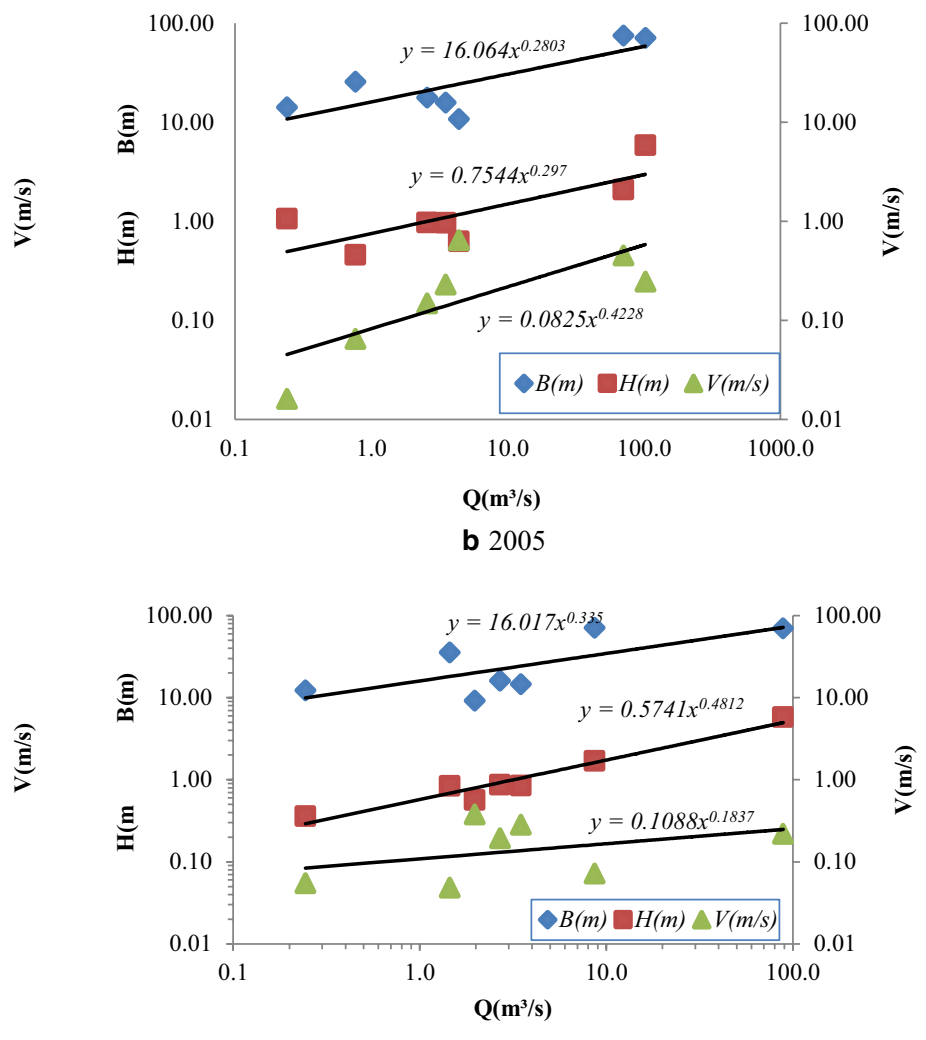

d 2007

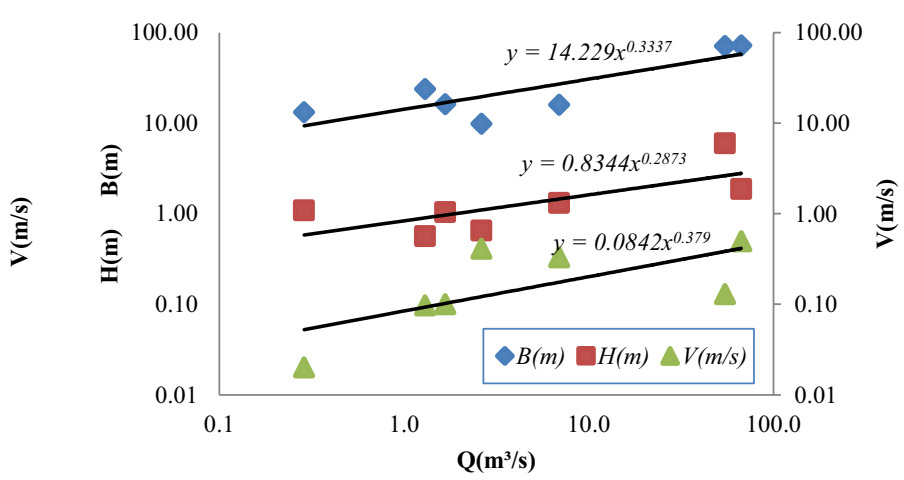

f 2009

Fig. 4 Relationship between discharge and downstream hydraulic geometry parameters 
Table 4 The exponents and coefficients of the downstream hydraulic geometry parameters

\begin{tabular}{|c|c|c|c|c|c|c|c|c|}
\hline \multirow[t]{2}{*}{ Year } & \multicolumn{3}{|c|}{ Exponents } & \multicolumn{3}{|c|}{ Coefficients } & \multirow[t]{2}{*}{$b+f+m$} & \multirow[t]{2}{*}{$a{ }^{*} c^{*} k$} \\
\hline & $b$ & $f$ & $m$ & $a$ & $c$ & $k$ & & \\
\hline 2004 & 0.3804 & 0.2580 & 0.3616 & 14.0860 & 0.5680 & 0.1250 & 1.0000 & 1.0001 \\
\hline 2005 & 0.2803 & 0.2970 & 0.4228 & 16.0640 & 0.7544 & 0.0825 & 1.0001 & 0.9998 \\
\hline 2006 & 0.3417 & 0.4611 & 0.1971 & 14.2400 & 0.4750 & 0.1478 & 0.9999 & 0.9997 \\
\hline 2007 & 0.3550 & 0.4812 & 0.1837 & 16.0170 & 0.5741 & 0.1088 & 1.0199 & 1.0005 \\
\hline 2008 & 0.3016 & 0.3759 & 0.3235 & 15.4190 & 0.6004 & 0.1080 & 1.0010 & 0.9998 \\
\hline 2009 & 0.3337 & 0.2873 & 0.3790 & 14.2290 & 0.8344 & 0.0842 & 1.0000 & 0.9997 \\
\hline 2010 & 0.3303 & 0.4824 & 0.1874 & 13.6700 & 0.4716 & 0.1551 & 1.0001 & 0.9999 \\
\hline Average & 0.33186 & 0.377557 & 0.29359 & 14.81786 & 0.61113 & 0.11591 & 1.0030 & 0.99992 \\
\hline
\end{tabular}

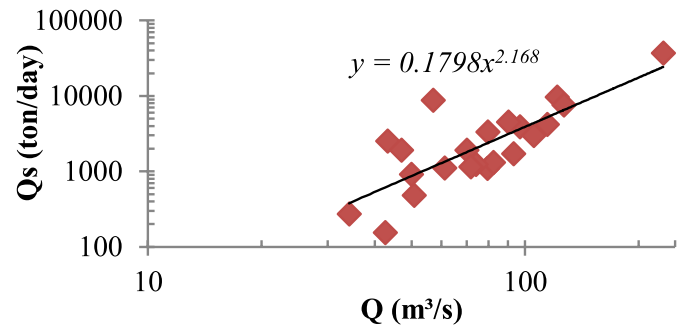

a E20A001

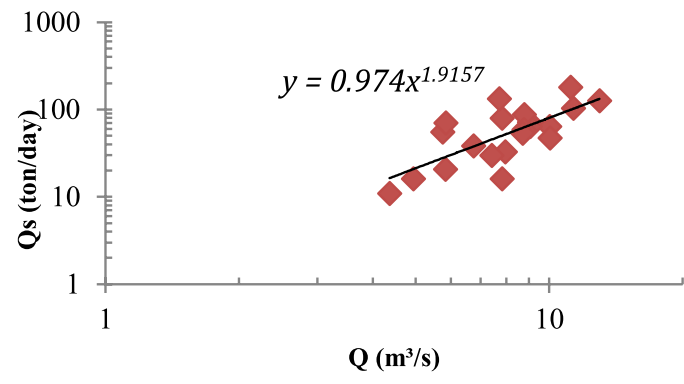

C $\mathrm{E} 20 \mathrm{~A} 015$
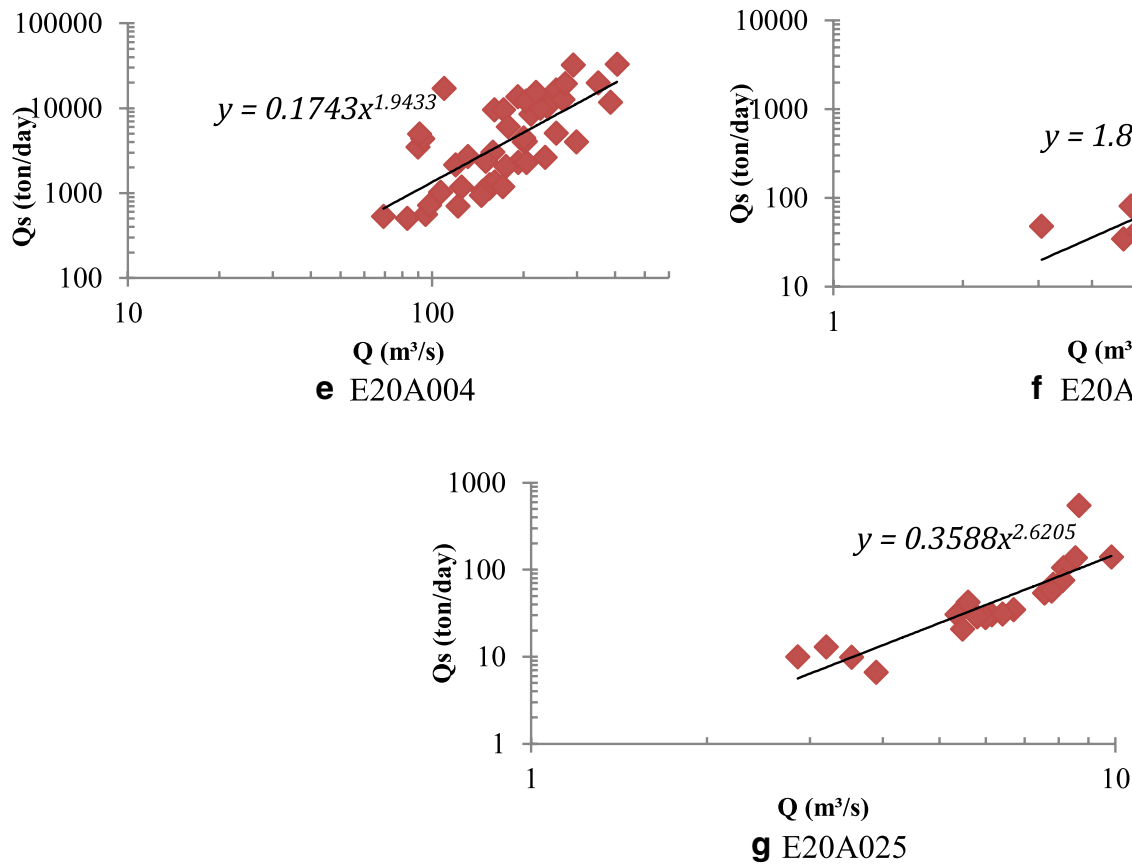
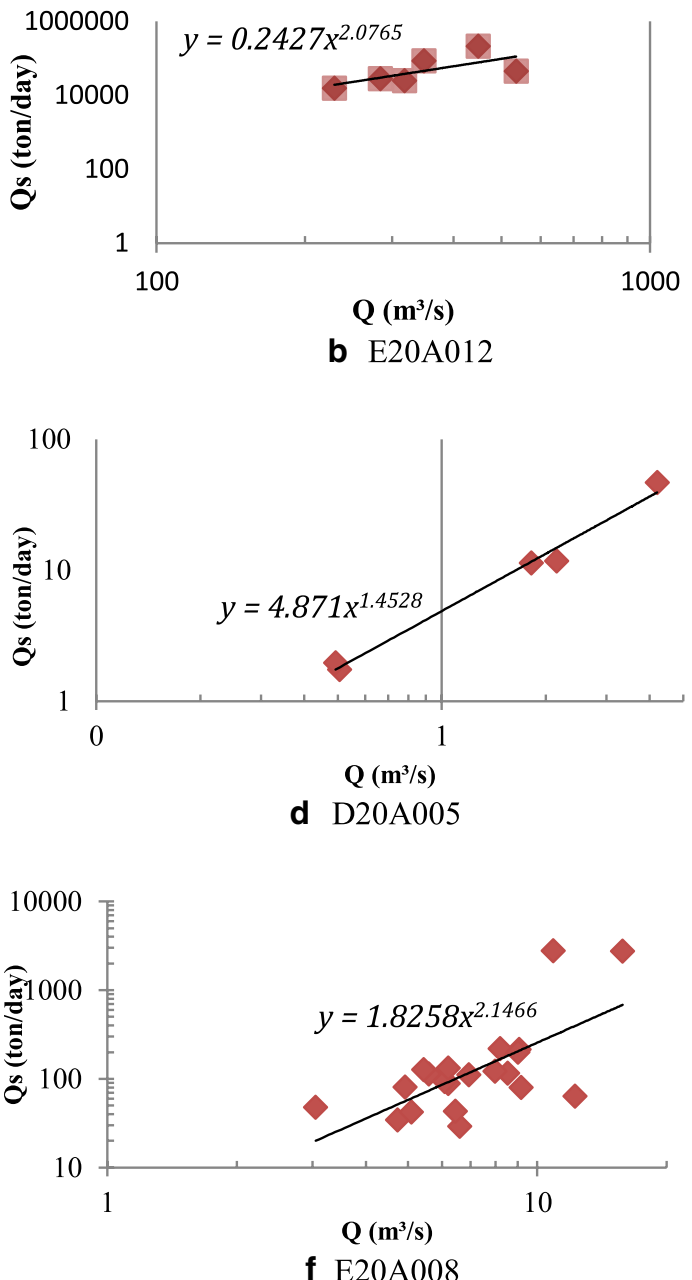

Fig. 5 Sediment rating curves $\left(Q_{s}-Q\right)$ for seven stations 

exponents of the relationship between sediment and flow discharges
Table 5 Coefficients and

\begin{tabular}{lll}
\hline Stations & $p$ & $j$ \\
\hline E20A001 & 0.1798 & 2.1680 \\
E20A012 & 0.2427 & 2.0765 \\
E20A015 & 0.9740 & 1.9157 \\
D20A005 & 4.8710 & 1.4528 \\
E20A004 & 0.1743 & 1.9433 \\
E20A008 & 1.8258 & 2.1466 \\
E20A025 & 0.3588 & 2.6205 \\
Average & 1.2323 & 2.0462 \\
\hline
\end{tabular}

the highest correlation coefficients as 0.80 and 0.832 for D20A005 and E20A025 stations, respectively. The highest correlation coefficients, in Pearson test, were noted to be 0.968 and 0.865 for D20A005 and E20A001 stations, respectively, while in Spearman test the highest correlation coefficients were observed to be 0.9 and 0.941 for D20A005 and E20A025 stations, respectively. As a result of these analyses, significant changes can be observed in the geometry of D20A005 and E20A025 stations, in time. The results of this study could be used to predict the crosssectional characteristics of the Ceyhan River at any point and might be useful for flood control, planning and management of hydropower generation.

\section{Conclusion}

Hydraulic geometry parameters and sediment transportation in a river are significant for water resources management, planning and controlling extreme hydrological events (flood and drought, etc.). In this study, ata-station and downstream hydraulic geometry analyses were performed for seven flow measurement stations of Ceyhan River over a period of 7 years. The analyses were conducted in the form of a power function, in order to define the relationship between the flow discharge and the river flow characteristics.

Channels in the Ceyhan Basin may adjust a consistent pattern computed by the concept of hydraulic geometry. Exponents and coefficients given in Tables 3 and 4 for downstream and at-a-station adequately state the general hydraulic geometry relationships for Ceyhan Basin in Turkey, and these relationships can be inferred for other basins when they have similar characteristics. Hydraulic geometry parameters for Ceyhan Basin have been compared nicely with previous published theoretical values. However, a considerable range of exponents and coefficients in both at-a-station and downstream due to different geologic, climatic physiographic and morphologic environments applying the basic hydraulic geometry approach vary between streams. In summary at-a-station, for all stations apart from E20A020 and EA20A022 surface width, mean depth and mean flow velocity were observed to increase with increasing flow discharge. In E20A020 and EA20A022 measurement stations, the mean depth was noted to slightly decrease with increasing discharge which signifies shallow and wide cross-sections. For downstream, the width, mean depth and mean flow velocity were observed to increase with increasing flow discharge.

In addition to hydraulic geometry analysis, sediment discharge-flow discharge relationship has also been investigated. According to the results, the relationships at D20A005 and E20A025 stations were found to be more significant compared to other stations in terms of correlation coefficient. Depending on this relationship, the volume of the sediment transported in Ceyhan River can be estimated. This study is expected to shed light for hydraulic works in Ceyhan basin.
Table 6 Correlation coefficients between sediment discharge and flow discharge

\begin{tabular}{|c|c|c|c|c|c|c|}
\hline \multirow[t]{3}{*}{ Stations } & \multicolumn{6}{|c|}{ Correlation coefficients } \\
\hline & \multicolumn{2}{|c|}{ Kendall } & \multicolumn{2}{|c|}{ Pearson } & \multicolumn{2}{|c|}{ Spearman } \\
\hline & tau & $p$ & $r$ & $p$ & $\rho$ & $p$ \\
\hline E20A001 & 0.558 & 0.000 & 0.865 & 0.000 & 0.706 & 0.000 \\
\hline E20A012 & 0.600 & 0.136 & 0.481 & 0.335 & 0.771 & 0.103 \\
\hline E20A015 & 0.486 & 0.002 & 0.670 & 0.001 & 0.647 & 0.002 \\
\hline D20A005 & 0.800 & 0.083 & 0.968 & 0.007 & 0.900 & 0.083 \\
\hline E20A004 & 0.554 & 0.000 & 0.692 & 0.000 & 0.699 & 0.000 \\
\hline E20A008 & 0.381 & 0.016 & 0.684 & 0.001 & 0.518 & 0.017 \\
\hline E20A025 & 0.832 & 0.000 & 0.538 & 0.015 & 0.941 & 0.000 \\
\hline
\end{tabular}




\section{Compliance with ethical standards}

Conflict of interest The authors declare that they have no conflict of interest.

Ethical standard This article does not contain any studies with human participants or animals performed by any of the authors. The manuscript does not contain clinical studies or patient data.

\section{References}

1. Leopold LB, MaddockT (1953) The hydraulic geometry of stream channels and some physiographic implications. U.S. Geological Survey Professional Paper, p 252

2. Singh VP (2003) On the theories of hydraulic geometry. Int J Sedim Res 18:196-218

3. Leopold LB, Wolman MG, Miller JP (1964) Fluvial processes in geomorphology. W.H. Freeman and Company, San Francisco, $p$ 522

4. Chong SE (1970) The width, depth and velocity of Sungei Kimla, Perak. Geographica 6:63-72

5. Richards KS (1976) Complex width-discharge relations in natural river sections. Geol Soc Am Bull 87:199-206

6. Park CC (1997) World-wide variations in hydraulic geometry exponents of stream channels: an analysis and some observations. J Hydrol 33(1-2):133-146

7. Huang HQ, Warner RF (1995) The multivariate controls of hydraulic geometry: a casual investigation in terms of boundary shear distribution. Earth Surf Proc Landf 20:115-130

8. Huang HQ, Nanson GC (1998) The influence of bank strength on channel geometry: an integrated analysis of some observations. Earth Surf Proc Landf 23:865-876

9. Parker G (1979) Hydraulic geometry of active gravel rivers. J Hydraul Divis Proc ASCE 105(HY9):1185-1201

10. Kolberg FJ, Howard AD (1995) Active channel geometry and discharge relations of U.S. piedmont and midwestern streams: the variable exponent model revisited. Water Resour Res 31(9):2353-2365

11. Howard AD (1980) Thresholds in river regimes. In: Coates DR, Vitek JD (eds) Thresholds in geomorphology. Allen Unwin, Boston, pp 227-258

12. Rhoads BL (1991) A continuously varying parameter of downstream hydraulic geometry. Water Resour Res 27(8):1865-1872

13. Allen PM, Arnold JG, Byars BW (1994) Downstream channel geometry for use in planning-level models. Water Resour Bull 30(4):663-671

14. Huang $H Q$, Nanson GC (1997) Vegetation and channel variation; a case study of four small streams in southeastern Australia. Geomorphology 18:237-249
15. Stewardson M (2005) Hydraulic geometry of stream reaches. J Hydrol 306:97-111

16. Lee SJ, Julien PY (2006) Downstream hydraulic geometry of alluvial channels. J Hydraul Eng 132:1347-1352

17. De Rose RC, Stewardson MJ, Harman C (2008) Downstream hydraulic geometry of rivers in Victoria, Australia. Geomorphology 99:302-316

18. Nanson GC, Huang HQ (2010) Bio-geomorphology and hydraulic geometry of narrow and deep channels in peatland floodplains; evidence for optimisation. Geomorphology 117(1-2):143-154

19. Muratoglu A, Yuce IM (2011) Determination of the downstream hydraulic geometry parameters of Tigris River. In: International conference on sediment transport modelling in hydrological watersheds and rivers, İstanbul, Turkey

20. Yuce MI, Esit M, Muratoglu A (2015) Determining the hydraulic geometry parameters of Seyhan River. Am J Eng Technol Soc 2:77-84

21. Wilson K (1966) Bed-load transport at high shear stress. J Hydraul Eng (Hydraul Divis) 92(11):49-59

22. Miller CR (1951) Analysis of flow duration sediment rating curve method of computing sediment yield. U.S. Department of the Interior, Bureau of Reclamation sedimentation Section, pp 3-15

23. Grunder M (1988) Soil conservation research in Ethiopia. Mt Res Dev 8:145-151

24. Hurni H, Kebede T, Gete Z (2005) The implications of changes in population, land use, and land management for Surface runoff in the upper Nile basin area of Ethiopia. Mt Res Dev 25:147-154

25. Eaton BC, Church M (2007) Predicting downstream hydraulic geometry: a test of rational regime theory. J Geophys Res 112:F03025. https://doi.org/10.1029/2006JF000734

26. Booker DJ, Dunbar MJ (2008) Predicting river width, depth and velocity at ungauged sites in England and Wales using multilevel models. Hydrol Process 22(20):4049-4057

27. Reid DE, Hickin EJ, Babakaiff SC (2010) Low-flow hydraulic geometry of small, steep mountain streams in southwest British Columbia. Geomorphology 2010(122):39-55

28. Aisuebeogun AO, Ezekwe IC (2014) Channel dynamics and hydraulic geometry of two tropical deltaic catchments in Southern Nigeria. Landf Anal 27:3-13. https://doi.org/10.12657/landf ana.027.007

29. Julien PY (2014) Downstream hydraulic geometry of alluvial rivers. In: Proceedings of a symposium held in New Orleans, LA, USA, 11-14 Dec 2014

30. Helmiö T (2004) Hydraulic geometry of cohesive Lowland Rivers. Boreal Environ Res 9:243-251

31. Rhodes DD (1987) The b-f-m diagram for downstream hydraulic geometry. Geogr Ann 69A(1):147-161

Publisher's Note Springer Nature remains neutral with regard to jurisdictional claims in published maps and institutional affiliations. 